\title{
White rot diseases of sunflower and measures against them
}

\section{Sardorjon AVAZOV ${ }^{1}$ Bakhrom SODIQOV ${ }^{2}$}

Tashkent state agrarian university, Tashkent, Uzbekistan

\section{ARTICLE INFO}

\section{Article history:}

Received September 2020

Received in revised form

15 September 2020

Accepted 15 October 2020

Available online

30 October 2020

\section{Keywords:}

Sunflower

Disease

Sclerotinia sclerotiorum

Fungicide

Biological effectiveness.

\begin{abstract}
This article presents the results of our experiments in the farm "Shonli Dior Fayz" in the Buka district of Tashkent region, the results of studies on the occurrence, spread of white rot disease in sunflower, symptoms of the fungus pathogen, the harm of the disease and the biological effectiveness of the applied fungicides.

Due to the fact that none of the fungicides allowed for testing in the Republic of Uzbekistan was recommended for use against sunflower white rot disease, the recommended norms for other crops for diseases with white rot were tested.

Based on the biology of pathogens, fungicides were used as control measures: Fundazol 50\% sp. - $2.0 \mathrm{~kg} / \mathrm{ha}$. and Difen super $55 \% \mathrm{sp}-0.25 \mathrm{~kg} / \mathrm{ha}$. and their biological efficiencies are determined
\end{abstract}

2181-1415/C) 2020 in Science LLC.

This is an open access article under the Attribution 4.0 International (CC BY 4.0) license (https://creativecommons.org/licenses/by/4.0/deed.ru)

\section{Белая гниль подсолнечника и меры борьбы с ними}

\begin{tabular}{l}
\hline Ключевые слова: \\
Подсолнечник \\
Болезнь \\
Sclerotinia sclerotiorum \\
Фунгицид \\
Биологическая \\
эффективность.
\end{tabular}

\section{АННОТАЦИЯ}

В данной статье приведены результаты наших опытов в фермерском хозяйстве “Шонли Диёр Файз” в Букинском районе Ташкентской области, данные результатов исследований о возникновении, распространении болезни белая гниль в подсолнечнике, симптомах возбудителя грибка, вреде заболевания и биологической эффективности примененных противных фунгицидов.

В связи с тем, что ни один из фунгицидов, разрешенных для испытаний в Республике Узбекистан, не рекомендован

\footnotetext{
${ }^{1}$ DSc, Professor, Tashkent state agrarian university, Tashkent, Uzbekistan

Email: sardorjon.avazov@mail.ru

${ }^{2} \mathrm{PhD}$, associate professor, Tashkent state agrarian university, Tashkent, Uzbekistan

Email: bakhrom-2019@mail.ru
} 


\begin{abstract}
для применения против болезни белая гниль подсолнечника, в опытах были проверены рекомендуемые нормы для других сельскохозяйственных культур при заболеваниях белая гнильем.

Исходя из биологии возбудителей в качестве мер борьбы были использованы фунгициды: Фундазол 50\% с.п. - 2,0 кг/га. и Дифен супер 55\% с.п. - 0,25 кг/га. и определены их биологические эффективности.
\end{abstract}

\title{
INTRODUCTION
}

According to R.O Ochilov (2008) and others, white rot of sunflower in Uzbekistan occurs during the growing season, mainly during the ripening period of sunflower, causing great damage to baskets. A temperature of $15-18$ OS is most favorable for this fungus. In areas affected by this disease, $15-20 \%$ of the crop is lost [5; 6].

According to VM Lukomets and co-authors (2011), the disease causes fungus Sclerotinia sclerotiorum (Lib) de Вагу. (=Sclerotinia libertiana Fuckel. Whetzelinia sclerotiorum Krof. Dumont).

The causative agent of the disease infects sunflower during the entire growing season. The disease manifests itself in various forms, but all of them are the result of local infection and are local in nature. Diffuse spread of mycelium does not occur. The pathogen has several forms of manifestation, depending on the period of infection of various organs and the nature of the damage to the host plant by the parasite: root, root, stem and basket $[1 ; 2 ; 3]$.

The disease affects young and older plants. From the time the grasses appear on young plants until the formation of six pairs of leaves, the disease usually appears in the form of seeds, stem base and white felt-like dust on the leaves. The upper part of the stem bends, and the leaves wither. White felt dust is also observed on the root surface and between parts of the soil. The roots soften and get wet. The dusty part of the plant stem turns brownish-brown, then its bark tissue is eroded, the conductive ligaments are stripped in the form of thin cords. Such a stem breaks, the whole plant dies and dries up. On the surface of the plant, as well as inside the stem, dark and black consistency, pathogenic sclerotia of various forms are observed.

In later damaged plants, the surface of the stem turns brown and the tissue becomes moist. The stem breaks and breaks. Sclerosis can be easily observed in it $[1 ; 3]$.

White rot is also often observed in the formed flower buds of sunflowers. Pale brown spots appear on the back of the basket, their texture is wet and easily crushed. The spots grow very quickly and occupy a large part of the basket. On their surface a white felt-like dust is formed, which penetrates to the seed $[2 ; 4 ; 6 ; 8 ; 10]$.

\section{METHODS AND OBJECTS OF RESEARCH}

In our experiments, we investigated the effect of certain fungicides that are allowed to be used against white rot in the Republic of Uzbekistan.

Fungicides were tested at the Shonli Dyer Fayz farm in Buki district, Tashkent region.

The treatments were carried out using a motorized knapsack sprayer, with a calculated working fluid flow rate of $1000 \mathrm{l} /$ ha by 2-fold spraying, the first before flowering sunflower May 26, the second 20 days later, after flowering. The experiments 
were laid in the morning, from 8 to 10 hours, when the air temperature did not exceed 26 ${ }^{\circ} \mathrm{C}$ and the wind speed was $1 \mathrm{~m} / \mathrm{s}$. Testing of the drug, accounting and processing of digital material was carried out according to the "Methodological guidelines ..." of the State Chemical Commission of the Republic of Uzbekistan (2004).

Scheme of experience:

1. Fundazol $50 \%$ sp. - $2.0 \mathrm{~kg} / \mathrm{ha}$

2. Difen super $55 \%$ sp. $-0.25 \mathrm{~kg} / \mathrm{ha}$

3. Control - no processing

The biological effectiveness of fungicides against diseases was determined by this formula $[6 ; 7 ; 9]$.

$$
C=\frac{(A b-B a)}{A b} * 100
$$

C - biological effectiveness, \%;

A - the average infestation of plant parts (leaves, shoots, baskets) in the experimental version, points in the raw time;

a - the average infection of the relevant parts of the plant in the experimental version, the scores after treatment (urgent 15, 30 or within 45 days);

B - average infestation of plant parts (leaves, shoots, baskets) scores in the control variant without treatment;

$\mathrm{b}$ - the average infection of the relevant parts of the plant in the control variant, the scores after treatment (urgent 15, 30 or within 45 days).

\section{RESULTS}

During our many years of research, it became clear that the disease of white rot in sunflowers in Uzbekistan is often observed during the ripening of baskets. Initially, it appears as brown spots on the back of the baskets, and over time, the spots enlarge, covering the entire basket and causing the basket to rot (Figure 1).

In our study in Tashkent region, when using Fundazol 50\% n.kuk., Scored 75 points. Difen super 55\% n.kuk used as a template. In the variant treated with $0.25 \mathrm{~kg} / \mathrm{ha}$, the incidence of disease after 15 days was 1.25 points in the baskets, 1.75 points after 30 days and 2.25 points after 45 days. In the uncontrolled variant, the highest damage was observed, in sunflower baskets the damage was 3.5 points after 15 days, 4.0 points after 30 days and 4.0 points after 45 days. 


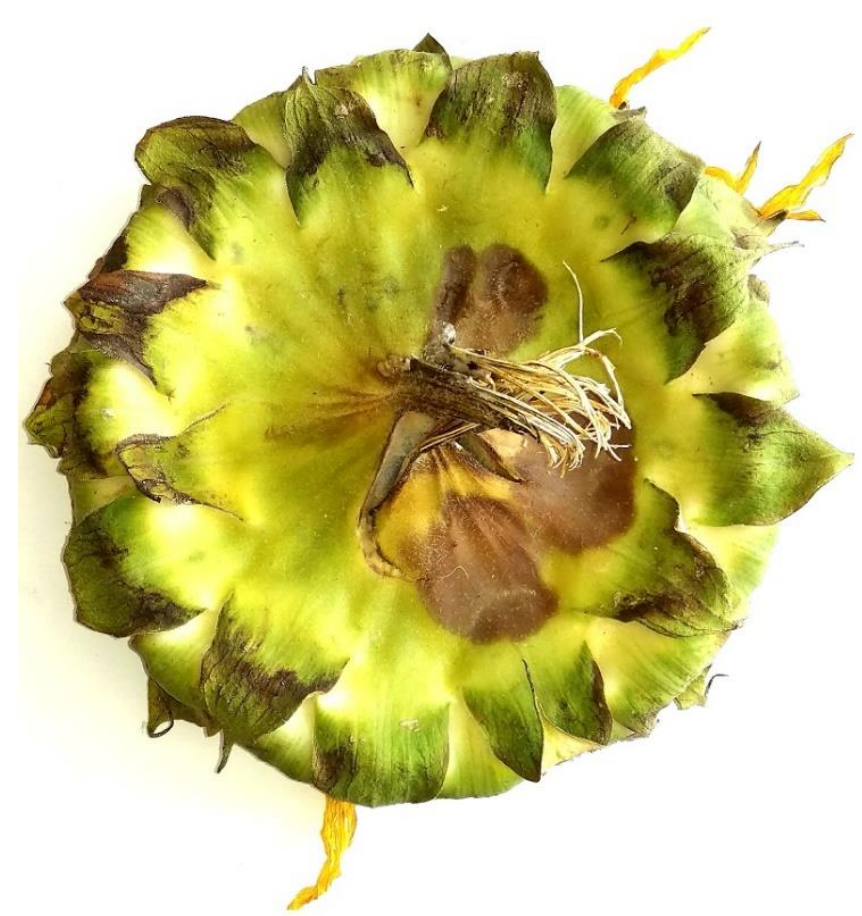

Fig. 1. The first appearance of white rot disease in a basket of sunflowers.

Table. -1

Lesions of rotten white sunflower

\begin{tabular}{|l|l|l|l|l|}
\hline \multirow{2}{*}{ Options } & \multicolumn{4}{|l|}{$\begin{array}{l}\text { Moderate damage of sunflower baskets with white rot } \\
\text { (points) }\end{array}$} \\
\cline { 2 - 5 } & $\begin{array}{l}\text { Before } \\
\text { processing }\end{array}$ & $\begin{array}{l}\text { After } \\
\text { days }\end{array}$ & $\begin{array}{l}\text { After } \\
\text { days }\end{array}$ & After 45 days \\
\hline $\begin{array}{l}\text { Difen super 55\% sp 0.25 } \\
\text { kg / ha }\end{array}$ & 2,75 & 1,25 & 1,75 & 2,25 \\
\hline $\begin{array}{l}\text { Fundazole 50\% s.p. 2.0 } \\
\text { kg / ha }\end{array}$ & 2,5 & 1,0 & 1,25 & 1,75 \\
\hline $\begin{array}{l}\text { Control without } \\
\text { processing }\end{array}$ & 2,75 & 3,5 & 4,0 & 4,0 \\
\hline
\end{tabular}

Data on the identified biological efficacy of fungicides in our experiments against white rot of sunflower are given in Table 2 .

As a result of our disease control experiments, Fundazol 50\% n.kuk. the highest biological efficiency was achieved in the variant treated at the rate of $2.0 \mathrm{~kg} /$ ha with fungicide. In particular, the development of the disease was $6.8 \%$ in leaves, $6.5 \%$ in stems and $6.4 \%$ in baskets, $78.8 \%$ in leaves, $80.9 \%$ in stems and $81.7 \%$ in baskets.

Difen super $55 \%$ used as a template. In the variant treated with fungicide at the rate of $0.25 \mathrm{~kg} / \mathrm{ha}$, the development of the disease was $8.2 \%$ in the leaves, $8.1 \%$ in the stem and $7.6 \%$ in the baskets, and the biological efficiency was $74.4 \%$ in the leaves and 76.2 in the stem. $\%$ and $78.3 \%$ in baskets.

In the untreated variant, an increase in disease damage was found. 
Table.-2

The biological effectiveness of fungicides against white rot of sunflower. (Production experience, Tashkent region, Buka district, f / x "Shonli Dior Fayz", 2018)

\begin{tabular}{|c|c|c|c|c|c|c|}
\hline № & Options & $\begin{array}{l}\text { Expense } \\
\text { rate }\end{array}$ & $\begin{array}{l}\text { Affected } \\
\text { Organs }\end{array}$ & $\begin{array}{l}\text { The } \\
\text { spread of } \\
\text { the } \\
\text { disease, } \%\end{array}$ & $\begin{array}{l}\text { The } \\
\text { development } \\
\text { of the } \\
\text { disease, } \%\end{array}$ & $\begin{array}{l}\text { Biological } \\
\text { efficiency,\% }\end{array}$ \\
\hline \multirow{3}{*}{1} & \multirow{3}{*}{$\begin{array}{l}\text { Difen } \\
\text { super } 55 \% \\
\text { sp } 0.25 \mathrm{~kg} \\
\text { / ha }\end{array}$} & \multirow{3}{*}{$\begin{array}{l}0,25 \\
\mathrm{~kg} / \mathrm{ha}\end{array}$} & Leaves & 10,1 & 8,2 & 74,4 \\
\hline & & & The stalks & 10,0 & 8,1 & 76,2 \\
\hline & & & Baskets & 11,3 & 7,6 & 78,3 \\
\hline \multirow{3}{*}{2} & \multirow{3}{*}{$\begin{array}{l}\text { Fundazole } \\
50 \% \text { s.p. } \\
2.0 \mathrm{~kg} / \mathrm{ha}\end{array}$} & \multirow{3}{*}{$\begin{array}{l}2,0 \\
\mathrm{~kg} / \mathrm{ha}\end{array}$} & Leaves & 7,2 & 6,8 & 78,8 \\
\hline & & & The stalks & 7,1 & 6,5 & 80,9 \\
\hline & & & Baskets & 6,9 & 6,4 & 81,7 \\
\hline \multirow{3}{*}{3} & \multirow{3}{*}{$\begin{array}{l}\text { Control } \\
\text { without } \\
\text { processing }\end{array}$} & \multirow{3}{*}{-} & Leaves & 10,0 & 32 & - \\
\hline & & & The stalks & 11,5 & 34 & - \\
\hline & & & Baskets & 11,5 & 35 & - \\
\hline
\end{tabular}

\section{CONCLUSIONS}

Based on the results of our experiment, it can be said that Fundazol 50\% in the fight against white rot disease of replanted sunflower plant. high biological efficiency can be achieved by treatment with fungicides at the rate of $2.0 \mathrm{~kg} / \mathrm{ha}$ and allows to obtain high yields from sunflower. Fundazol 50\% n.kuk. fungicide can be recommended against the white rot disease of sunflower.

\section{REFERENCES}

1. Hodenkova A. M. Biological substantiation of the protection system of oilseed sunflower from a complex of diseases / Anna M. Hodenkova // Abstract. dis... agricultural sciences. - Minsk, 2018.P. - 26.

2. Kholmuradov E.A., Avazov S.E., Sattarova R.K. Agricultural phytopathology Tashkent, 2013 - 787 p.

3. Lukomets V. M., Piven V. T., Tishkov N. M. Diseases of sunflower. Agrorus, 2011.P. $-210$.

4. Muradasilova N.V. Influence of sunflower sclerotinia on sowing quality of seeds. Scientific and technical bulletin of the All-Russian Scientific Research Institute of Oilseeds 2006, 2 (135). -P. 61-66.

5. Ochilov R.O and others. Temporary recommendations on measures to control pests and diseases of oilseeds. Tashkent "Talqin" 2008. $16 \mathrm{p}$

6. Sodikov B.S. Fungal diseases of sunflower and measures to combat them / Sodikov Bahrom Sattarovich // Abstract. dis ... PhD. agricultural sciences. - Tashkent, 2019.P. - 34. 
7. Sodikov B.S. Chemical protection Helianthus Annuus L. of Botrytis cinerea Pers. // Bulletin of Science and Practice. - Moscow, 2018. - № 4. - P. 219-222.

8. Sodikov B.S., Kholmuradov E.A., Avazov S.E. White rot disease of sunflower plant and its control. // Journal of agrochemical protection and plant quarantine. - Tashkent, 2018. - № 5. - P. 54-55.

9. Sodikov B.S., Хужаев О.T. Chemical protection of sunflower against Alternaria. // Journal Actual problems of modern science. - Moscow, 2019. - № 4. - P. 188-199. 